Универзитет Метрополитан у Београду, Универзитет уметности у Београду, Факултет драмских уметности,

Београд

DOI 10.5937/kultura1339273P

УДК 316.77:172

070.11

32.019.5:172

стручни рад

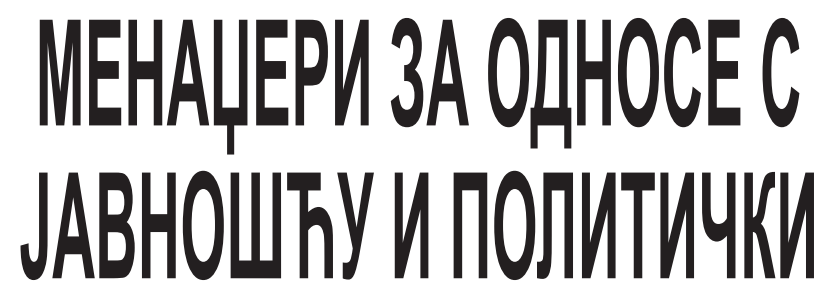

QУНКLИОНЕРИ-

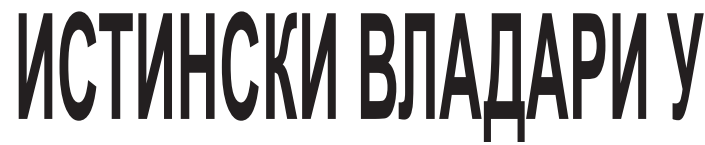

KOMYHWKALYOHOM

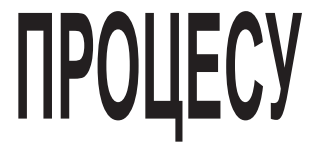

Сажетак: Рад проблематизује питање економских и политичких утицаја на новинаре и медијске институције и поставља тезу да су менацери за односе с јавношћу и политички функционери они који најчешће владају комуникационим процесом. Преиспитује се улога и одговорност медијских радника који су најизложенији економским и политичким притисиима и утицајима, односно свих оних који користе медије за сопствене интересе. У раду се образлажу неки од чланова Етичког кодекса новинара Србије у вези с истинитошћу извештавања и независности од притисака, а који се по мишљењу аутора рада често крше у свакодневној новинарској пракси. Како постоје многобројни механизми манипулације којима се служе агенције за односе с јавношћу које заступају комерцијалне клијенте и граде имиц политичких партија и њихових функиионера, закључујемо да су њихови утицаји често снажнији 
од новинарске етике и професионалног поступања медија, ито их тренутно чини истинским владарима у комуникационом процесу, а јавност и друштво чини подложним манипулацијама.

Кључне речи: политички и економски утицаји, медијска манипулачија, новинарска етика, новинарска слобода, етички кодекс новинара

\section{Увод}

У недовољно дефинисаним и нестабилним друштвеним условима какви управо карактеришу Балкан и Србију у првој деценији XXI века, медији и култура у целини су под сталним преиспитивањем. Масовни медији су међу најутицајнијим организацијама у друштву, пошто се налазе на раскршћу између грађана и њихових политичких, економских и друштвених институција. С тим у вези, медијски радници су кључни за преношење основних друштвених вредности и нуде симболичне путоказе за стандарде поступања, укључујући и етичко понашање. ${ }^{1}$ Новинари имају свакодневни приступ подацима и покушавају да пруже тачне информације грађанима, како би ови могли да створе ставове и донесу одлуке засноване на обавештености. При томе не смемо заборавити на чињеницу да комерцијални медији морају да поштују и захтеве тржишта који се огледају у задовољењу апетита јавности за сензационалнијим и спектакуларнијим аспектима живота, односно за насилним и сексуално експлицитним садржајем и константном фасцинацијом приватним животом истакнутих људи.

Новинари нису једини медијски радници који обављају функцију дистрибуирања информација у друштву, стога, разматрати питање етике информисања не значи задржати се на преиспитивању њиховог етичког поступања. Ту не смемо заборавити економске поруке оглашивача и рад агенција и менаџера за односе с јавношћу на изградњи имиџа компанија и појединаца пошто они такође пружају мноштво информација циљним групама и јавности, генерално гледано.

Деловање и доношење одлука медијских професионалаца треба да је мотивисано искључиво у складу са својом савешћу и захтевима професије о истинитости, праведности, објективности у презентирању ситуације, програмирању садржаја, итд. Но, паралелно са напретком друштва, комуникација и свести, напредовале су и технике манипулације. Медијска манипулација представља аспект рада односа

1 Корни, Д. (1999) Етика информисања, Београд: Клио, стр. 50. 
с јавношћу у којем одређене особе и интересне групе настоје да створе слику или аргументе који погодују њиховим специфичним интересима. Могућност да се утиче на људски ум, те да се посредством тога усмерава људско понашање у жељеном правцу, представља значајан научни, али и морални проблем.

Утицај техника манипулације у друштву, које себе доживљава као „друштво комуникације”, стално се појачава, јер технике, не наилазећи готово ни на какав отпор, освајају не само свет политике, рекламе, односа са јавношћу, већ и емоције и друге међуљудске односе. ${ }^{2}$

Медијски професионалци изузетно су утицајни у обликовању јавног мњења, али њихово деловање може имати много реперкусија на животе појединаца. Етика јавне речи је изузетно комплексно подручје и не односи се само на новинарство и уређивачке колегије медија, већ на све учеснике у процесима масовног комуницирања, све политичаре, интелектуалце, уметнике и друге који су у прилици да стално или повремено огласе своја размишљања кроз медије.

\section{Економски и политички утицаји на медије - претварање медија у дистрибутера информација и пут ка криену етичких стандарда}

Масовни медији имају посебно виђење своје друштвене улоге и раде под посебним финансијским ограничењима, што их чини карактеристичним учесницима у политичкој, економској, социјалној и културној динамици друштвене моћи. Коментаришући утицај медија на криминално понашање Алвин Луис Деј извео је овај логички закључак: „Ако толики комерцијални и политички интереси улажу толико новца у медијско оглашавање, апсурдно је веровати да медији немају утицај на наше понашање. У супротном, оглашивачи су протраћили милијарде долара““.

Први члан Етичког Кодекса новинара Србије тиче се истинитости извештавања и обавезе новинара да тачно, објективно, потпуно и благовремено извести о догађајима од интереса за јавност, поштујући право јавности да сазна истину држећи се основних стандарда новинарске професије. У демократском друштву посвећеном слободном протоку информација, тачност чињеница је очигледан етички

2 Бретон, Ф. (2000) Изманипулисана реч, Београд: Клио, стр. 9.

3 Алвин Деј, Л. (2008) Етика у медијима, Београд: Клуб Плус, стр. 230. 
императив, чак и када се неповољно одражава на владину политику.

Медији су дужни да интерес јавности за потпуним, благовременим и истинитим информисањем ставе изнад свих других интереса, а интерес јавности, према поменутом Кодексу, подразумева објављивање свих важних информација које су од помоћи при формирању властитог суда или мишљења о појавама и догађајима. Рад новинара смешта се унутар односа одређеног медија и његове публике. Сваки медиј предлаже одређено читање тренутне реалности коje је прилагођено његовој представи о сопственој публици и одговара оним очекивањима за која се претпоставља да постоје. С тим у вези, медији се усмеравају према потребама тржишта које би требало да представља инструмент регулисања.

Новинар не сме слепо да верује извору информација, што је такође наведено у Кодексу као и да мора да води рачуна о томе да ти извори често следе своје интересе или интересе друштвених група којима припадају, те своје исказе прилагођавају томе. Посебна пажња неопходна је у контакту са изворима информација како би се избегла стварна или привидна пристрасност. О непосредној користи коју извор може остварити од објављивања информације јавност мора да буде обавештена пошто извор може да има непосредан интерес, или настоји да се с неким обрачуна.

Данас је истраживачко новинарство у дефанзиви, јер комерцијални аспект медијске индустрије и све више дешавања, те генерално убрзање живота утиче на уреднике да све више инсистирају на брзини објављивања вести. У тој брзини се наравно праве и грешке, али далеко већа опасност лежи у непотпуном проверавању информација. Оне се врло често добијају од прес служби, ПР менаџера и саветника за медије. Њихов интерес готово по правилу јесте да се објави одређена информација или прича на одређени начин како би извршили утицај на аудиторијум-одређене циљне групе или јавност у целости. Једна од апотеоза вођења односа с јавношћу јесу добри односи са медијима. У практичном смислу то значи одржавање добрих односа са новинарима и уредницима, те медијским кућама (без обзира на персоналне промене које су релативно честе у новинарству). Управо у томе и лежи највећа опасност, јер је генерална деградација новинарског посла, изражена у споменутој трци за информацијама и објављивањем истих (која новинаре претвара у сервис за прослеђивање информација и прилога), утицала на смањење независности новинара и смањење финансијског аспекта бављења овим послом. Новинари, на жалост, нај- 
чешће више нису лучоноше демократије и друштвеног развитка и услед описане деградације све су подложнији утицају политичара, са једне, и ПР менаџера и саветника, с друге стране. ${ }^{4}$ Јавна је тајна у многом транзиционим земљама да се новинари могу поткупити одређеним услугама и стварима (на пример плаћеним одморима или лап топ рачунарима), а неретко и директном новчаном трансакцијом. То жалосно стање, судећи према садашњој ситуацији, нема тенденцију враћања, већ пре погоршања.

У Кодексу се такође наводи да је прећуткивање чињеница које могу битно да утичу на став јавности о неком догађаjy, једнако њиховом намерном искривљивању или изношењу лажи. Корни каже да „са професионалног становишта, благонаклона и повољна реч и саучесничко ћутање налазе се у истој равни јер је у оба примера, реч о ниподаштавању или изопачавању слободе информисања“,, а директне жртве таквог поступка су истина и право јавности да сазнаје истину. Уколико су извори информација портпароли политичких странака, појединаца и компанија, тај податак мора да се наведе јер је могућ њихов директан или индиректан утицај на објективност извештавања. Ово је један од најчешћих проблема који се у последњих двадесетак година јавља у новинарству,

Да новинар треба да се супротстави сваком притиску на слободно обављање професије, као и сваком виду цензуре, наглашава се у Кодексу новинара Србије као и да новинар задатке прима само од надлежних уредника. Неопходно је да се новинари одупру свим спољашњим притисцима који имају за циљ да их одврате од основне одговорности да јавност истинито, правовремено и свестрано информишу. Требало би да се подразумева одбијање свих корумптивних понуда и разних видова поткупљивања, непосредних или посредних, јер се ту гради или руши интегритет новинара и кредибилитет професије. „Минхенска декларација важност те чињенице поткрепљује на тај начин што „примање мита сваке врсте, било ради објављивања или заташкавања информације”, сврстава међу тешке повреде професије“. ${ }^{6} \mathrm{Je}-$ дан од најочитијих и најконкретнијих аспеката рада новинара јесте то да новинар ни на који начин не сме извлачити

4 Перић, Н., Красуља, Н. и Радојевић, И. (2012) Медијске, ПР и бренд тендениије, друго, допуњено, издање, Београд: Synopsis и Чигоја штампа, стр. 13.

5 Корни, Д. (1999) Етика информисања, Београд: Клио

6 Војновић, Ђ. (2004) Облици новинарске саморегулације и одговорности, у: Етика јавне речи у медијима и политици, Београд: Центар за либерално демократске студије, стр. 180. 
никакву корист, било материјалну или моралну из обављања своје професије, што важи пре свега за однос новинара према изворима од којих добија информације. Ако је у питању новац или стицање било какве добити ценкањем и нагодбом, новинар мора то категорично одбити. У пракси су ситуације далеко магловитије како тврди Стевановић (2012), јер се новинарима дају примамљиве понуде најчешће зато да би се постигло објављивање благонаклоног чланка или неке повољне информације из којих се може извући добит. Тиме се организовано баве агенције за комуницирање и односе с јавношћу, специјализоване за разна предузећа, а понекад чак и државне установе или високи државни чиновници. Циљ је да се штампа претвори у „пуког дистрибутера” одређене информације коју фабрикује неко други. Директне жртве таквог поступка су истина и право јавности да је сазна.

Како тврди Мирољуб Радојковић, тимови рекламера и ПР стручњака вребају сваку прилику да своју робу и клијенте прокријумчаре кроз селекцију материјала за објављивање, и при томе не бирају средства, односно, не питају за цену. Прикривена реклама, улагивање спонзорима, стављање потписа на новинарску форму коју је припремио ПР службеник уз надокнаду, итд. су феномени који данас привлаче највише пажње свих регулаторних тела и бораца за професионалну етику новинарства у развијеним државама. ${ }^{7}$

Етика у новинарству понајвише се коси са економским и политичким интересима и често од истих бива поражена. Управо се у члану три Кодекса новинара Србије наводи да "политички и економски интереси издавача не смеју да утичу на уређивачку политику, на начин који би имао за последицу нетачно необјективно, непотпуно и неблаговремено информисање јавности." Сведоци смо да се поједини штампани и електронски медији у јавности перципирају као "послушници" одређених политичких партија. Дешавало се да се неки дневни листови оснивају уочи избора и недвосмислено потенцирају одређену политичку групацију. Јасно је да су у том случају нарушени основни етички принципи, и чини се да ће се овакав тренд нажалост наставити. Питање политичког маркетинга и етике обухвата разматрање етичке димензије политичког маркетинга и ПР-а као концепције комерцијализоване варијанте политичке пропаганде и свега оног што политички маркетинг и ПР обухватају - „његове методичке постулате, технике, принципе утврђивања стратегије маркетиншких кампања, различите стратегије

7 Радојковић, М. (2004) Кодекси професионалне етике у новинарству, у књизи Етика јавне речи у медијима и политици, Београд: Центар за либерално демократске студије, стр. 62. 
промоције, садржаје који се и начине на који се садржаји промовишу, аргументацију, односно псеудоаргументацију која се користи у промоцији, начине коришћења појединачних средстава и облика промоције, ефекте кампања итд“.8

Још један проблем који смо поменули тиче се економских притисака. Стручњаци у области маркетинга и односа с јавношћу као примаран циљ имају да преко медија допру до својих циљаних јавности како би наметнули одређени став или изазвали интересовање које за циљ има њихову економску добит. Упрошћено речено, односи с јавношћу подразумевају целокупну организацију комуникације једне организације, дакле и све оне елементе који се могу сврстати у новинарство, маркетинг и уопште комуникацију. Овде се манипулише већ у фази припремања поруке чиме се директно утиче на примаоца поруке. Проблематично с односима с јавношћу јесте то што лаж није дозвољена, али јесте истицање свега онога што организацији иде у корист. Како је овде прекршена главна етичка премиса попут објективности, тачности и истинитости, етички проблеми постају очигледни.

У етичком Кодексу новинара Србије експлицитно се наводи да се сваки вид комерцијалног оглашавања, као и политичке пропаганде, које нису јасно означени, сматрају тешким прекршајем стандарда професионалног поступања новинара. Филип Бретон истиче да нико не може да тврди да је сврха рекламе обавештавање о нечему. Њена сврха није у обавештавању, већ у утицају на промену понашања потрошача (или гласача, у случају политичког маркетинга), или утицај на промену навика. ${ }^{9}$ Информација представља само једно од средстава у процесу утицаја. Текст који је платио оглашивач не сме потписати ни уредник ни неки други професионални новинар. У пракси, ствари нису баш до те мере јасне, јер оглашивач прибегава разним лукавствима да би његов текст што више личио на новинарски текст. Новине иначе садрже известан број рубрика чији је карактер двосмислен (на пример: мода, аутомобили, туризам), те се под плаштом чињења услуге читаоцу који је, неоспорно, заинтересован за новости, често крије чињење услуге неком стварном или потенцијалном оглашивачу или интересној групи. Делатност стручњака за комуницирање и других служби за односе са јавношћу појачава опасно дејство таквих услуга, јер ти стручњаци и те службе покушавају да се "увуку" у

8 Славујевић, 3. (2004) Политички маркетинг и етика, у књизи Етика јавне речи у медијима и политици, Београд: Центар за либерално демократске студије, стр. 116.

9 Бретон, Ф. (2000) Изманипулисана реч, Београд: Клио, стр. 50. 
новинарски простор и запоседну га помоћу благонаклоних чланака.

У вези са економским притисцима и моралном одговорношћу новинара, овдашње околности доносе нам мноштво примера и проблематизују економске интересе који иду против моралних обавеза новинара. Како наводи Стевановић (2012), уколико се осврнемо на листе најмоћнијих људи у медијима у Србији које се саопштавају већ неколико година уназад, приметићемо неколико интригантних чињеница. Поред власника највеће приватне медијске корпорације у региону и директора јавног сервиса, једно од првих десет места заузима директор маркетинга највеће овдашње приватне привредне компаније. Објашњење за овај медијски утицај у вези је с улагањима у оглашавање - поменута компанија је највећи оглашивач у нашој земљи, а финансијска средства која се у те сврхе издвајају умногоме утичу на медијске садржаје. Поред ове компаније, у самом врху најутицајнијих људи налазе се власници маркетиншких и агенција за односе с јавношћу. Према Роленду Лоримеру, ${ }^{10}$ „утицај бизниса на масовне медије врши се како кроз оглашавање, тако и тражњу која проистиче из корпоративне форме дотичног медијског канала.“ Одлуке бизниса о томе где he се оглашавати и колико ће на то трошити, утичу на судбину појединачних медијских предузећа јер како би привукли огласе, запослени у медијима у најмању руку, труде се да не увреде (или да потенцијално не увреде) оглашиваче и старају се да се садржај медија не судара с порукама оглашивача. Оглашавање је општеприсутна појава у медијском систему и представља економску основу за масовне комуникације, те тако директно утиче на квалитет медијског садржаја. Свакако, оглашавање даје медију финансијску независност од владе и других политичких интереса, али ствара и зависност од комерцијалног сектора, а кад комерцијални притисци угрозе новинарске стандарде, морају се решавати озбиљна етичка питања.

Када се комерцијалним интересима омогући да доминирају над другим друштвеним обавезама јављају се многа етичка питања. У овом случају оно гласи како наћи равнотежу између економских притисака и појединачних или институционалних обавеза према другима. Уласком у нови век медији су се придружили великим бизнисима, а економски притисци агресивно се боре за утицај на одлуке које доносе уредници. Када маркетиншке стратегије доводе до неприродног савеза забављачких и новинарских вредности, и када

10 Лоример, Р. (1998) Масовне комуникације, Београд: Клио, стр. 52. 
нарушавају императив медија да опслужују демократски систем кроз расправу о озбиљним и друштвено значајним питањима, етичке дилеме су неизбежне. Поједини аутори ${ }^{11}$ тврде да су рекламне агенције и менаџери за односе с јавношћу истински владари у комуникационом процесу и да искоришћавају неспособност или неспремност пасивних потрошача да уоче и разврстају сурови бараж манипулативних комуникација. Помирење њихових позиција мало је вероватно и можда је највише што се може очекивати, успостављање минималних стандарда прихватљивог понашања и расподела моралне одговорности међу различитим играчима у ланцу комуникација.

Професионалци, задужени за односе са јавношћу и комуницирање, су у служби органа из државног сектора или предузећа која припадају приватном сектору. Једна од функција тих професионалаца за комуницирање јесте да постигну да медији објављују повољне информације о њиховим послодавцима или о органима који су им поверили мандат да се баве питањима комуникације. ${ }^{12}$ Новинари морају стално бити будни и на опрезу како би избегли да се у информисање увуку паразити пропаганде и спречили остваривање нечијих личних циљева. Свака етичка индискретност, додатно умањује поверење друштва у медије.

Наредни угао посматрања везе између етике, политике, манипулације и медија могла би бити визура у којој се у нашем медијско-политичком систему бележи све више новинара и осталих медијских стваралаца који се у различитим функцијама укључују и постају кључни актери политичког живота. Нису само економски интереси ти који утичу на медије и стварају многе етичке недоумице. Подједнако с њима стоје и политички интереси. Утицај који влада врши на масовне медије споља, има неколико димензија. Влада је за масовне медије главни информативни извор. Проток информација од владе до масовних медија доноси корист обема странама. Влади је потребно да има приступ медијским каналима како би информисала јавност о својим програмима и давањима. Масовним медијима су информације, којима их она снабдева, потребне као одмах употребљив извор медијског садржаја на тему текућих и послова од јавног значаја. Међутим, ова пријатна узајамна услужност ствара и међусобну зависност. Главна мана ове зависности је у томе што јавни интерес може да исклизне из своје повлашћене силе

11 Christians C. G., Fackler M., Rotzoll K. B. and McKee K. B. (2001) Media ethics: cases \&moral reasoning, New York: Addison Wesley Longman, p. 127.

12 Корни, Д. (1999) Етика информисања, Београд: Клио, стр. 69. 
која покреће медије, у корист трампе услуга владе и медија. Због споменутог временског шкрипиа и ограничености извора, посленици медија су склони да се превише ослањају на саопштења за штампу и већ припремљене папире које им влада подели. Пропустом да завире у оно што је иза ових обзнана, медијски канали ризикују да послуже као владина пропагандна оруђа.

Политичари су вредни вести, а дневно покривање политичких догађаја суштински је део садржаја масовних медија. Међутим, функција медија и њихов утицај на комуникационе процесе у друштву су, чини се, и важнији и већи него политичара, због тога што су политичари део медијске, а не личне стварности човека. Грађанин ретко има прилику да доживи политичара непосредно, него што га реципира кроз медијски филтер који га представља селективно. У моћи ствараоца вести је да посебно истакну, коментаришу или потпуно прећуте говор политичара или акт неке организације или институције, а једно од правила медијске комуникације гласи - оног што нема у медијима, не постоји у јавности. Тако медији теоретски имају моћ и над политичарима, јер они по својој процени и према уређивачкој политици одлучују када ће и на који начин политичари бити приказани. Но, у пракси, медији су под јаким утицајем политичара и прес служби са једне и оглашивача и ПР менаџера са друге стране.

\section{Закључак}

Медији морају да деле моралну одговорност за срозавање демократских вредности у оној мери у којој је јавност одустала од озбиљног садржаја у замену за баналност. Али када медији нису одани демократском мандату да опслужују друштвени систем који им је омогућио да постоје, они постају културно дисфункционални и систему ускраћују виталност. ${ }^{13}$ Етички стандарди медијских стручњака нису одвојени од остатка друштва. Они који раде у медијима морају да разреше своје етичке недоумице кроз исти процес моралног резоновања као и сви остали. Због чињенице да заузимају тако кључну и истакнуту позицију у комуникацијским каналима друштва, новинари морају да буду на челу оних који стварају моралне ставове у овом друштву. Но, услед наглог срозавања новинарства у целости и новинара као члана друштва, јасно је да стручњаци за односе с јавношћу и продуценти масовне забаве добрим делом обликују медијску слику и јавно мњење, а то је сигуран пут ка манипулацији и

13 Алвин Деј, Л. (2008) Етика у медијима, Београд: Клуб Плус, стр. 105. 
укидању истине. У таквом друштву, у којем је новац замена за истину, онемогућен је сваки развој и напредак, тако да би овим проблемом, осим медијских теоретичара и практичара, требало да се баве и други представници јавности, те друштво у целости.

\section{ЛИТЕРАТУРА:}

Алвин Деј, Л. (2008) Етика у медијима, Београд: Клуб Плус Бретон, Ф. (2000) Изманипулисана реч, Београд: Клио

Бригс, А. и Кобли, П. (2005) Увод у студије медија, Београд: Клио Christians C. G., Fackler M., Rotzoll K. B. and McKee K. B. (2001) Media ethics: cases \&moral reasoning, New York: Addison Wesley Longman

Група аутора (2004) Етика јавне речи у медијима и политици, Београд: Центар за либерарно-демократске студије

Корни, Д. (1999) Етика информисања, Београд: Клио

Лоример, Р. (1998) Масовне комуникаиије, Београд: Клио

Никшић, С. и Давичо, А. (2004) Етика новинарства, приручник за професионалне новинаре, Београд: Центар за професионализацију медија

Перић, Н., Красуља, Н. и Радојевић, И. (2012) Медијске, ПР и бренд тендениије, друго, допуњено издање, Београд: Synорsis и Чигоја штампа

Радојковић, М. (2004) Кодекси професионалне етике у новинарству, у књизи Етика јавне речи у медијима и политищи, Београд: Центар за либерално демократске студије

Славујевић, 3. (2004) Политички маркетинг и етика, у књизи Етика јавне речи у медијима и политици, Београд: Центар за либерално демократске студије

Стевановић, А. (2012) Економски и политички утицаји на новинаре као узрок медијске манипулаиије, часопис Медијски дијалози (Подгорица), Vol. V, No. $13-14$

Васиљевић Благојевић, М. и Перић, Н. Однос новинара и ПР менаџера у функцији унапређења екстерних односа с јавношћу, у: II Међународни научни скуп о развоју тржишне комуникације - Моћ комуникаиије, (2013) Београд: Висока струковна школа за пропаганду и односе с јавношћу

Васовић, М. (2004) Пропагандне (убеђивачке) технике у служби маниплуације јавним мњењем, у: Етика јавне речи у медијима и политици, Београд: Центар за либерално демократске студије

Војновић, Ђ. (2004) Облици новинарске саморегулације и одговорности, у: Етика јавне речи у медијима и политици, Београд: Центар за либерално демократске студије 
Вуксановић, Д. (2010) Етика и дислексија, Култура бр. 127, Београд: Завод за проучавање културног развитка

Европска конвенција о људским правима и основним слободама

Кодекс новинара Србије - упутства и смернице, Фондација Конрад Аденауер

Оснивачки акт Савета за штампу Србије

Статут Савета за штампу

Минхенска декларација о правима и обавезама новинара Европске заједнице

Nenad Perić and Ana Stevanović

Metropolitan University, Belgrade,

University of Arts, Faculty of Dramatic Arts, Belgrade

\title{
ECONOMIC AND POLITICAL INFLUENCES ON JOURNALISTS AS A CAUSE OF MEDIA MANIPULATION
}

\begin{abstract}
The paper treats the issue of economic and political influences on journalists and the media institutions. Autors' thesis is that public relations managers of political officials are the true rulers in the communication process. The media employers and journalists are most exposed to the economic and political pressure and influence by all those who use the media for their own interests. The paper has searched the articless of the Code of Ethics of Journalists in Serbia regarding veracity of reporting and independence of pressure, which are often violated in everyday journalistic practice. As there are many mechanisms of manipulation used by Public Relations agencies representing commercial clients or building images of political parties and their officials, authors have concluded that their influence is often stronger than the journalistic ethics and the rules of professional conduct in the media, which currently makes them true rulers of the communication process and leave the public and the society vulnerable to manipulation.
\end{abstract}

Key words: political and economic influences, media manipulation, journalistic ethics, journalistic freedom 